Forthcoming in Australian Journal of Human Rights - draft, please do not cite without permission.

\title{
Irremediable impacts and unaccountable contributors: the possibility of a Trust Fund for Victims to remedy large-scale human rights impacts
}

\section{David Birchall}

\begin{abstract}
Corporate actions often adversely impact human rights in ways that are not easily justiciable. Such actions include the production and use of fossil fuels, contributing to climate change and its impacts, and actions that deny or retrogress access to the global food, housing and pharmaceutical markets. This paper terms the impacts caused by these actions "large-scale impacts". Such impacts feature multiple contributors, disparate victims, and no clear line of causation for establishing individual liability, and they often stem from legally permitted economic activity. This paper argues that the corporate responsibility to respect human rights - pillar two of the UN Guiding Principles on Business and Human Rights (UNGPs) - provides a useful framework for: (1) capturing the harm that such impacts cause, and (2) holding a wide range of businesses accountable for their contribution. However, remedial mechanisms under pillar three of the UNGPs, as currently constituted, are ill-suited to such impacts. To correct this gap, this paper proposes the establishment of a Trust Fund for Victims (TFV), into which all corporate contributors to large-scale impacts would pay and against which victims could claim. Such a mechanism could significantly improve corporate accountability in the context of economic globalisation.
\end{abstract}

\section{Introduction}

Corporations can adversely impact human rights through their economic activity, including through acts or omissions that are not considered paradigmatic human rights violations. For example, the pollution that corporations create can harm individuals' health (Seck 2016), their housing investments can restrict low-income individuals' access to housing (Farha 2017), their trading in food commodity derivatives can impact individuals' access to food (Chadwick 2018), and their tax avoidance can restrict a 
Forthcoming in Australian Journal of Human Rights - draft, please do not cite without permission.

state's ability to protect rights (Darcy 2016). These acts cause demonstrable, often severe, harm to individuals' enjoyment of human rights, but they are not easily captured by current constructions of accountability and remedy (Birchall 2019a). Each of the examples above is particularly significant because of the scale at which it occurs. While the acts of a single company might cause only minimal impacts, the cumulative effect of multiple companies' acts could be severe. Climate change-causing pollution is the most extreme example of this, both in terms of the number of contributors and the scale of (potential) harm.

Affected individuals would benefit significantly from the introduction of a means to capture, prevent and remedy these impacts. This paper argues that responsibility under pillar two of the UN Guiding Principles on Business and Human Rights (UNGPs) encompasses such impacts (UNGPs, Principle 13). ${ }^{1}$ It builds this argument through the definition of 'human rights impact' therein and the tripartite "cause/contribute/linked to" attribution framework. A human rights impact occurs when a business's action 'removes or reduces the ability of an individual to enjoy his or her human rights' (OHCHR 2011, 5). If a business enterprise causes or contributes to an action that removes or reduces an individual's enjoyment of rights, that business has a responsibility to prevent, mitigate and/or remedy the harm, as appropriate (UNGPs,

${ }^{1}$ This paper addresses the corporate responsibility to respect human rights only. It is beyond this paper's scope to address in depth the state duty to protect human rights (UNGPs' pillar one) or wider state obligations under international law. However, as this paper argues, states could provide the institutional structure for this paper's proposed remedial mechanism as part of their duty to ensure that 'those affected have access to effective remedy' (UNGPs, Principle 25). 
Forthcoming in Australian Journal of Human Rights - draft, please do not cite without permission.

Principle 13a). If a business does not cause or contribute to the impact but is linked to the impact by a business relationship, that business has a responsibility to use its leverage over its business relation to attempt to prevent or mitigate the impact (UNGPs, Principle 13b).

Therefore, the evaluative criterion of 'adverse human rights impact' (UNGPs, Principle 13) is that a business action causes, contributes to or is linked to the removal or reduction of individuals' enjoyment of human rights, with both causal and contributory responsibility engendering direct responsibility to prevent, mitigate and/or remedy. This paper argues that large-scale impacts produced by corporate actions meet the criteria of 'adverse human rights impacts', because they contribute to the removal or reduction of individuals' enjoyment of human rights. For example, the act of releasing carbon dioxide relevantly contributes to adverse impacts through climate change, air pollution and more (Judson, Schmalensee and Stoker 1998).

Contributory impacts come in two forms: "cumulative" and "assistive". Largescale impacts are predicated on the cumulative form of impact, where multiple firms each contribute a relatively minor amount to the creation of a substantial impact (DIHR 2016). The assistive form, on which John Ruggie (2017), the drafter of the UNGPs, recently elaborated, is also relevant to large-scale impacts. This form suggests that contributory responsibility arises where a business contributes goods, services or other assistance to another business, the actions of which cause an impact, where the contributor knowingly enables and fails to mitigate that impact. As such, many harmful acts may meet the criteria of 'adverse human rights impacts' (UNGPs, Principle 13), and many companies are potentially contributing to these impacts. 
Forthcoming in Australian Journal of Human Rights - draft, please do not cite without permission.

That such impacts can be captured by the UNGPs demonstrates the UNGPs' transformative potential to reshape global business (Birchall 2019b). However, largescale impacts also evidence a gap in pillar three of the UNGPs, access to remedy. No remedial form listed therein or since enacted effectively captures unaccountable contributors or provides remedy to all victims of large-scale impacts, primarily because each of them relies on victims making specific claims against specific firms (Scheltema 2013; Knuckey and Jenkin 2015). To this end, this paper proposes the establishment under pillar three of a Trust Fund for Victims (TFV) of human rights impacts, broadly modelled on the TFV established under the Rome Statute (Arts 68(3), 75 and 79) and with several precedents in international and domestic law. A TFV would allow firms that contribute to large-scale impacts through their economic activity to fund remedies for the disparate victims of those impacts, without having to accept specific moral or legal culpability or directly address the complex harm themselves.

This paper initially discusses the nature of large-scale impacts. It then turns to the definition of 'adverse human rights impacts' under the UNGPs (Principle 13) and the criteria that need to be met for a company to have contributed to an impact. It then examines access to remedy, highlighting the gap around large-scale impacts, and reviews various extant models designed to address similar large-scale issues. Finally the paper develops a model TFV and concludes.

\section{The problem of large-scale impacts}

The following criteria define large-scale impacts: first, the human rights of large numbers of individuals are adversely impacted; second, multiple corporations contribute to the impact; third, and resultantly, there is no clear line of causation from an individual corporation to the harm suffered by an individual victim; fourth, the harmful 
Forthcoming in Australian Journal of Human Rights - draft, please do not cite without permission.

acts are often part of (quasi)-legitimate global economic activity, and so do not constitute paradigmatic human rights violations. This leads to an accountability gap, because no single corporation can be reasonably held liable for the impact on a specific victim. $^{2}$ In its guidance on the corporate responsibility to respect human rights, the Office of the High Commissioner on Human Rights (OHCHR) (2011) provides examples of adverse human rights impacts, which, in some of their forms, would meet these criteria - for example, some 'human rights issues that result from environmental impacts', including water and health-related issues stemming from ocean acidification and air pollution (OHCHR 2011, 53).

Many large-scale impacts have been discussed in the context of the UNGPs, though not always in a systematic way. The OHCHR has stated that businesses must be 'accountable for their climate impacts' (OHCHR 2016, 3), and John Knox (2016, para. 66; 2018, para. 18), the former UN Special Rapporteur (UNSR) on human rights and the environment, has elaborated on various business responsibilities related to climate change that emerge from the UNGPs. A petition to the Philippine Commission on Human Rights (PCHR), drafted by Greenpeace et al. (2015), attempts to use the UNGPs to hold fossil fuel companies accountable for the human rights impacts of climate change in the Philippines. The UNSR on the right to housing (Farha 2017, paras 62-66) has condemned the human rights impacts of financialised housing predicated on the

\footnotetext{
${ }^{2}$ States could certainly regulate some of these issues more effectively, but many of
} these issues are transnational and not easy for states to capture through traditional regulatory means. This paper argues that the TFV could indeed spur improved regulation and thereby encourage companies to reduce their adverse impacts on human rights. 
Forthcoming in Australian Journal of Human Rights - draft, please do not cite without permission.

severe macro-level retrogression of affordability within many jurisdictions (Farha 2017, para. 4). Literature is also developing around the impacts being created through the transnational food regime (McMichael 2012; Chadwick 2018; Ferrando 2019). A paradigmatic example is the contribution that multiple large agribusiness firms made to the 2007 Global Food Crisis, when they switched en masse from growing food to producing biofuels (De Schutter 2008; 2009). Shane Darcy (2016) and two UNSRs (Sepúlveda Carmona 2014; Bohoslavsky 2015) have argued that tax avoidance can have a human rights impact.

This article focuses on showing that pillar two of the UNGPs is capable of capturing "large-scale impacts" rather than on mapping the full empirical scope and limits of that term. It may be that the framework more easily captures climate change than tax avoidance, for example, because climate change's human rights impact is both more direct and more endemic to normalised business practice.

What these examples share is that they are prevalent, harmful and not conducive to traditional (justiciable) remedies. Many large-scale impacts are ongoing, cannot be prevented completely, and, because they are tied to legitimate economic activity, engage a wide range of contributors. The essence of this paper's argument is that, while all specific impacts should be reduced as far as possible, global economic activity will continue to cause some human rights impacts that should be remedied through an ongoing process. To understand how the UNGPs' framework addresses such impacts, this paper now turns to the definition of 'adverse human rights impacts' in the UNGPs (Principle 13).

\section{Human rights impacts under the UNGPs}

This section discusses what constitutes an 'adverse human rights impact' under pillar 
Forthcoming in Australian Journal of Human Rights - draft, please do not cite without permission.

two of the UNGPs (Principle 13). The corporate responsibility to respect human rights requires business enterprises to avoid causing or contributing to 'adverse human rights impacts' through their own activities, including both acts and omissions; to address such impacts when they do occur; and to seek to prevent or mitigate adverse human rights impacts that are directly linked to their operations (UNGPs, Principle 13). According to the OHCHR $(2011,5)$, '[a]n "adverse human rights impact" occurs when an action removes or reduces the ability of an individual to enjoy his or her human rights'. Therefore, business acts, even legally permitted ones, that remove or reduce access to rights constitute human rights impacts. The term "impact" is therefore broader than most conceptions of the term "violation". Noting the greater inclusivity of the term “impact", Deva $(2013,98)$ defines "violation" as the "causation of legal injury to [an identified set of people] in terms of a breach of human rights'. The inclusion of acts that reduce the enjoyment of rights means that even acts that cause quantitative reductions in access to water, healthcare or housing, for example, are considered. This opens up the UNGPs to include a wide range of large-scale impacts.

The related concept of retrogression, introduced under the International Covenant on Economic, Social and Cultural Rights (ICESCR), can help us to understand what is meant by reducing the enjoyment of rights. The Committee on Economic, Social and Cultural Rights (CESCR) has stated that the ICESCR prohibits retrogressive measures unless they can be justified by reference to the totality of the rights that the ICESCR prescribes (CESCR 1990, para. 9). Retrogressive measures include removing or reducing de jure guarantees of rights and 'empirical backsliding in the effective enjoyment of the rights' (Courtis, Lusiani and Nolan 2014, 123). This latter type of retrogressive measure is the most relevant to corporations. It requires 'the 
Forthcoming in Australian Journal of Human Rights - draft, please do not cite without permission.

use of quantitative indicators' to measure 'objective socio-economic outcomes' (Courtis, Lusiani and Nolan 2014, 124), such as the level of access to food. A retrogression in quantitative access to a right constitutes a "prima facie violation of the [ICESCR]' (Courtis, Lusiani and Nolan 2014, 124). States are therefore judged on quantitative outcomes. Where retrogressions in access occur, they are process traced back to government policies. They might then be deemed retrogressive measures in breach of the ICESCR.

A corporate act that reduces the enjoyment of rights constitutes a human rights impact of a similar form to a retrogressive measure (Birchall 2019a, 138-139). For example, the housing investor Blackstone Group L.P. (Blackstone) is alleged to have bought 'undervalued' homes in low-income areas, significantly raised rental prices, and then evicted the low-income tenants (Deva and Farha 2019). The company is not accused of having breached the law. However, if these allegations are true, Blackstone would have reduced access to affordable housing for many individuals and, therefore, reduced their enjoyment of the right to housing on the core criterion of 'affordability', as defined in the CESCR's General Comment on the right to housing (CESCR 1991, para. 8).

Such acts are not easily justiciable, but they do have a serious adverse impact on human rights (Farha 2017, paras 34-38). Taking this outcome-oriented approach in relation to large-scale impacts is crucial, if we are to embed comprehensive respect for human rights in the global economy at a time when corporate profit-seeking frequently contributes to reduced access to human rights.

The UNGPs use the concept of 'severity' (Principle 24) to determine which impacts should be prioritised, if prioritisation is required. This is useful for large-scale 
Forthcoming in Australian Journal of Human Rights - draft, please do not cite without permission.

impacts, which could, in some way, affect millions, even billions, of individuals. The most severe impacts should be prioritised based on their 'scale, scope and irremediable character' (UNGPs, Principle 14). Scale relates to the 'gravity' of the harm, scope to the number of individuals affected, and irremediability to 'limits on the ability to restore those affected to a situation at least the same as, or equivalent to, their situation before the adverse impact' (OHCHR 2011, 83). The switch to biofuels by agribusiness firms, mentioned earlier, caused severe impacts, at least in terms of 'scale' and 'scope'.

Climate change impacts are severe in terms of all three criteria.

Because the acts that give rise to large-scale impacts are often (quasi-)legitimate forms of global economic activity, there is a plausible normative rationale to exclude them from, or at least deprioritise them within, any framework of human rights

responsibility. In a moral sense, it is understandable that human rights violations such as slavery would be given precedence (Arnold 2016). In a business sense, corporations would prefer for their responsibilities to be limited to such violations. Conferring on businesses responsibility for large-scale impacts in circumstances where the underlying business acts are legal would increase the scope of responsibility significantly. For this reason, a specific and appropriate remedial solution is required. Increasing the scope of responsibility would also likely increase the number of potential contributors. This paper considers to whom responsibility would be attributed next.

\section{Attribution of responsibility}

This section discusses how responsibility for human rights impacts is attributed under the cause/contribute/linked to framework (UNGPs, Principle 13). Under the UNGPs, '[w]here business enterprises identify that they have caused or contributed to adverse impacts, they should provide for or cooperate in their remediation through legitimate 
Forthcoming in Australian Journal of Human Rights - draft, please do not cite without permission.

processes' (UNGPs, Principle 22). If the firm is 'directly linked', through its operations, products or services, to an impact caused by another firm, it has no responsibility to remediate but should 'seek to prevent and mitigate' the impact (UNGPs, Principle 13b) by using its leverage over the other firm to encourage prevention, mitigation and/or remediation (UNGPs, Principle 19b). Therefore, the relevant question, for the purpose of an eventual TFV, is whether a firm has caused or contributed to the impact or is merely linked to the impact. As noted, contributory responsibility comes in two forms, cumulative and assistive.

A cumulative contribution occurs when a business act contributes a small amount to a larger impact. The Danish Institute of Human Rights (DIHR) $(2016,65)$ describes cumulative impacts as 'the successive, incremental and combined impacts from multiple projects or multiple activities located in the same region or affecting the same resource'. ${ }^{3}$ This is highly relevant for large-scale impacts, including pollution, and marketised human rights, such as the rights to housing and food, where individual businesses might not have monopoly power but the sum total of market actors causes a reduction in access to the right. According to the DIHR $(2016,66)$, a situation where 'cumulative water use due to tourism development reduces water tables, resulting in drought with widespread effect on food security in the local community' is an example of a cumulative impact. A report into the impacts of tourism in Myanmar provides further examples: the increased presence of tourism businesses has led to '[i]ncreased

\footnotetext{
${ }^{3}$ Although the DIHR $(2016,63)$ document discusses 'human rights impact assessments', a concept that predates the UNGPs, it uses the UNGPs' definition of human rights impacts, explicitly stating that '[i]mpacts to which the business contributes include cumulative impacts' (65).
} 
Forthcoming in Australian Journal of Human Rights - draft, please do not cite without permission.

prices [for] food and goods' and increases in rents, displacing residents; and 'waste disposal by hotels, restaurants and tourists' is causing '[r]educed fish catches' and 'disruptions to [the] marine environment' (DIHR, MCRB and IHRB 2015, 118).

The OHCHR uses as an example of a contributory impact the '[t]argeting [of] high sugar food and drink to children, with an impact on child obesity'. This is probably also a cumulative impact. An individual company is unlikely to produce either an easily identifiable victim or make a significant quantitative contribution to child obesity. Rather, it contributes to a large-scale cumulative crisis. Cumulative impacts go hand-inhand with many large-scale issues.

Regarding pollution causing climate change, the relevant questions are: is climate change causing human rights impacts, and are businesses contributing to climate change? Regarding the retrogression of affordability of housing, similar questions apply: is retrogressing affordability reducing individuals enjoyment of the right to housing, and are companies contributing to this retrogression? If both are answered in the affirmative, these businesses are responsible for their contributions.

Assistive contributions occur when a company assists another actor that is adversely impacting human rights. The $\operatorname{OHCHR}(2011,17)$ provides some examples fitting this categorisation:

\footnotetext{
Providing data about Internet service users to a Government that uses the data to trace and prosecute political dissidents contrary to human rights; [p]erforming construction and maintenance on a detention camp where inmates were allegedly subject to inhumane treatment.
}

It also suggests that 'financial loans to an enterprise for business activities that, in breach of agreed standards, result in the eviction of communities' are an example of a link that generates no remedial responsibility (OHCHR 2011, 17). The OHCHR 
Forthcoming in Australian Journal of Human Rights - draft, please do not cite without permission.

provides no further explanation of these examples. The three examples are fundamentally similar, in that the business in question has provided a service (data provision; construction; loans) towards a human rights impact. The difference in the last example is that the enterprise to whom the loans were provided breached agreed standards, which is indicative of a pre-emptive attempt to prevent or mitigate the impact.

In a 2017 paper on the implications of the UNGPs for corporate and investment banking, the Thun Group of Banks $(2017,6)$ adopted a more minimal reading of contributory impacts:

While the provision of wholesale financial products and services may under specific circumstances reach the level of contribution, in an investment banking context banks are $[\ldots]$ more likely to be directly linked to adverse human rights impacts under UNGP $13 b[\ldots]$.

Despite admitting that, in some cases, provision of financial services might 'reach the level of contribution', the paper obfuscated and otherwise ignored the issue (Thun Group of Banks 2017, 6). David Kinley $(2017,2)$ responded by writing that ' $[\mathrm{t}] \mathrm{he}$ critical question is of course, where is that inflexion point?', and John Ruggie $(2017,2)$ responded by attempting to clarify the 'continuum' between contribution and linkage:

A variety of factors can determine where on that continuum a particular instance may sit. They include the extent to which a business enabled, encouraged, or motivated human rights harm by another; the extent to which it could or should have known about such harm; and the quality of any mitigating steps it has taken to address it. Asserting that only a bank's own activities can constitute 'contributing to' harm, as the paper does, bypasses these critical questions entirely [emphasis added]. 
Forthcoming in Australian Journal of Human Rights - draft, please do not cite without permission.

Ruggie's (2017) comments, in which he establishes a set of three indicia, help to answer Kinley's question and are relevant to all large-scale harms. According to Ruggie, where a company: (a) had knowledge; (b) enabled, encouraged or motivated the impact; and (c) failed to mitigate that harm, it is firmly at the 'contributory' end of the continuum. Ruggie does not clarify whether this definitively means that the company has contributed, but it would appear to be the case, unless the company could make a strong counterargument. Any less definitive interpretation would render the conceptual apparatus of the continuum purposeless. We could extrapolate from this that, if a firm knowingly enables and fails to adequately mitigate a human rights impact, it has prima facie contributed to that impact. For many impacts that are also serious human rights violations, such as slavery, connected companies might well have no knowledge of the impact. Such impacts are known to be wrong and are frequently hidden, which is why human rights due diligence is a key requirement of the UNGPs (UNGPs, Principle 17). But, for the large-scale impacts that are part of normal economic activity, the knowledge criterion is generally met. Banks, for example, can be reasonably expected to know that a loan to a fossil fuel company or a policy that facilitates tax avoidance risks contributing to the relevant adverse impact.

If assistive contributions are taken into account, many firms would appear to contribute to many different impacts. If a company's marketing of junk food to children is an impact and firms that knowingly enable that impact contribute to it, firms that provide products and services to the company would be contributors, as would its investors and lenders. The junk food company could also be contributing to other impacts, such as environmental harm through agribusiness, perhaps linked to palm oil production (Feintrenie, Rist and Levang 2010). In many cases of large-scale impact, a 
Forthcoming in Australian Journal of Human Rights - draft, please do not cite without permission.

small group of firms is most directly implicated, but a much larger range has enabled or encouraged the impact in full awareness of the harm involved. This is certainly true of climate change, where the 'carbon majors' produce vast amounts of fossil fuels, but which other firms then use (CDP 2017). In other words, firms in multiple industries encourage, and indeed necessitate, fossil fuel production. Moreover, the impacts are known and, at best, only partially mitigated. One question that remains is therefore whether providing assistance to a cumulative impact also constitutes a contribution to that impact. While there must be a point at which a contribution is so minor as not to engender responsibility, the literature does not state that assistance to a cumulative impact cannot engender responsibility. The answer would hinge on the severity of the impact and the importance of the assistance. Wider discussion of the specific limits would be beneficial.

The cause/contribute/linked to framework is useful for seeing the global economy as an interconnected web, in which firms rely on one another rather than operate as atomised units (Ruggie 2018, 318-319; Wettstein 2009, 12-13). However, corporations are only responsible for their own contribution to an impact (UNGPs, Principle 19). This is useful for establishing a quantitative approach to large-scale impacts, to which numerous firms contribute small amounts. Individual contributions are often relatively minor and therefore individual remedial responsibility should be minor. Imposing remedial responsibility is not necessarily to allege moral culpability; rather, it is to state that corporations participate in and derive extreme benefits from the global economy, which is laced with externalities that are harmful to human rights, and they should therefore accept responsibility for the harms caused. For this reason, it is useful to take a comprehensive approach to large-scale impacts. This requires an 
Forthcoming in Australian Journal of Human Rights - draft, please do not cite without permission.

effective and efficient means through which all corporations can assist in the remedying of large-scale impacts to which they contribute. The next section looks at current remedial options under the UNGPs.

\section{Access to remedy}

Many business acts reduce the enjoyment of human rights and many businesses play a contributory role in these adverse human rights impacts. Remedial mechanisms that rely on an individual or delineated group asserting a specific claim against a specific firm or group of firms are unsuited to many such impacts (Miller-Dawkins, Macdonald and Marshall 2016), because they adopt what Linklater $(2011,79)$ terms an 'interactional' view of harm. Unfortunately, this is the form most clearly advocated under pillar three of the UNGPs. The 'foundational principle' of access to remedy is that 'States must take appropriate steps to ensure [...] that when such abuses occur within their territory and/or jurisdiction those affected have access to effective remedy' (UNGPs, Principle 25). This includes 'judicial mechanisms', 'non-judicial grievance mechanisms', 'nonstate based grievance mechanisms', and, for business enterprises, 'operational-level grievance mechanisms' (UNGPs, Principles 26-29). The UNGPs also provide that '[i]ndustry, multi-stakeholder and other collaborative initiatives [...] should ensure that effective grievance mechanisms are available' (UNGPs, Principle 30).

Operational-level grievance mechanisms imply a specific grievance against a specific firm, and so are unsuited to large-scale impacts in most cases. Judicial mechanisms are hampered by the problems, innate in tort law, of proximity and burden of proof for such impacts (Augenstein 2018). While non-judicial mechanisms and nonstate based mechanisms offer more flexibility, these also rely, in practice, on close causal links to a specific firm. One example is the National Contact Point (NCP) 
Forthcoming in Australian Journal of Human Rights - draft, please do not cite without permission.

mechanism established under the OECD (2011) Guidelines for Multinational Enterprises. Despite being separate to the UNGPs, the Guidelines' chapter on human rights covers the same rights as the UNGPs and adopts the UNGPs' language and principles, including "human rights impacts" and the cause/contribute/linked to attribution framework (OECD 2011, 31).

This is a useful example because OECDWatch has established a large database of NCP cases. Studying the NCP database reveals a many cases that go much further than feasible claims in tort, but none that concerns a large-scale impact. Communities frequently challenge multinational corporations over impacts, ranging from displacements (OECDWatch 2015, 30-31) to the 'negative consequences' of their exports on local livelihoods (OECDWatch, n.d.), but engaging a specific company is still required (OECDWatch 2017, 35). As such, NCPs largely exclude those impacts caused by multiple contributors and with disparate victims. Moreover, NCP cases are rarely successful. An OECDWatch (2015) study found that only 14\% of cases resulted in some type of remedy-related outcome. An OECD (2016) study found that $15 \%$ of cases resulted in 'agreement', which did not always include remedy. A 2018 study revealed that just one case of the eighteen completed in 2017 resulted in financial compensation (OECDWatch 2018).

These mechanisms are ill-suited to large-scale impacts because of three major structural problems. First, these mechanisms require a specific group to target a specific firm or set of firms. While the claimant can be a group bringing a class action, this group must have been similarly affected, and it is very difficult to target multiple firms in such an action. Second, even the most inclusive of the mechanisms exist in the shadow of the norms of legal responsibility, not least because they are voluntary. These 
Forthcoming in Australian Journal of Human Rights - draft, please do not cite without permission.

norms hamper what both the institutions and firms are likely to consider reasonable claims. Moreover, because of the interactional nature of these mechanisms, providing remedy would be akin to accepting responsibility, which could lead to a floodgates concern (Musalo 2006). Third, such methods are a laborious and expensive means by which to remedy the harm caused. This guarantees that many victims will fail to claim. A mechanism is needed that would reduce the burden on both victims and corporations and allow all contributors to an impact to contribute a small amount to a joint remedial effort.

Despite these limits under pillar three of the UNGPs, it remains true that, in the above cases, business acts have caused and contributed to adverse human rights impacts. According to the UNGPs, these impacts require remedy. That human rights impacts should be remedied must be lexically prior to the suggested forms of remedy under pillar three. If pillar three fails to provide for each form of impact, it should be strengthened; the unacceptable alternative would be that some human rights impacts are ignored. The aforementioned efforts of various UNSRs, Greenpeace, and other scholars to capture what this paper terms large-scale impacts have a sound basis in the UNGPs, in particular the definition of 'human rights impact' and the "cause/contribute/linked to" attribution framework, but are hindered by pillar three. Exposing this gap helps to explain why such cases have so frequently failed. Such cases are not beyond the scope of the UNGPs; rather, the technical limitations of pillar three leave victims without an appropriate remedial mechanism. This allows us to consider possible means by which to address the gap.

Such an approach coheres with the normative perspective of the UN Working Group on Business and Human Rights (UNWG), which is grounded in 'holistic 
Forthcoming in Australian Journal of Human Rights - draft, please do not cite without permission.

remedies' (2017, para. 80). The UNWG (2017, para. 2) states that 'if a human right is breached, the holder or holders of the right should be able to seek remedies from the duty bearers', where the term "remedies" is 'construed holistically to address both individual and societal goals' (para. 80). UNWG (2017, para. 18) emphasises the 'centrality of rights-holders' in the remedial process. This comes through in UNWG's (2017, para. 38) suggestions that a 'bouquet of remedies' might be needed to meet rights holders' needs and that any remedial process provided by the duty bearer should 'take both the rights holders and their suffering seriously' (paras 14, 19).

In the next section, this paper proposes establishing a TFV under the UNGPs to address the remedy gap identified above.

\section{A Trust Fund for Victims}

Corporations frequently contribute to human rights impacts in the normal course of business without taking responsibility for remediation. To remedy large scale impacts, this paper suggests that two fundamental elements are required: first, financing from firms that have contributed to those impacts; and second, a fair method of determining which impacts should be addressed, given that the financing will, inevitably, be limited. A TFV would allow all corporations that contribute to some form of human rights impact, whether through their impacts on the environment, their provision of services, or another means, to contribute a small amount to fund remedy. A TFV was proposed in the "zero draft" of the Binding Treaty on Business and Human Rights (Human Rights Council 2018; Birchall, forthcoming), but this proposal was removed from the updated draft (Human Rights Council 2019).

The large-scale harms discussed above could benefit from improved human rights due diligence and, in some cases, a more comprehensive approach to other forms 
Forthcoming in Australian Journal of Human Rights - draft, please do not cite without permission.

of remedy. They might also require a range of remedies, including guarantees of nonrepetition and symbolic remedies. However, as the UNWG (2017, para. 45) has acknowledged, 'compensation is the most commonly sought and granted remedy for business-related human rights abuses'. Financial remedy to restore the original position of the victim is most appropriate for large-scale impacts because moral fault is less relevant and prevention might be best addressed by other means, such as green technologies and healthy-eating campaigns. Compensation need not only include direct compensation to victims; it could also take the form of project finance or communal remedies.

As a practical starting point, a TFV could be voluntarily established by corporations, in cooperation with non-governmental organisations. In this form, the TFV would likely begin by targeting a specific problem and a specific set of contributors, such as climate change and those businesses that contribute to it. This would be a sensible way to initiate what is admittedly an ambitious idea. However, it would ideally be established and enforced by states, including through international organisations, and be open to all victims of large-scale impacts. This approach would help realise the foundational principle of pillar three, that states have a duty to provide access to remedy for harms caused by business (UNGPs, Principle 25).

The TFV would also help address one of the most contentious areas of contemporary human rights law, that of extraterritorial, or transnational, state obligations (De Schutter 2012; Gibney 2013a; Seck 2019). Under the UNGPs, where a set of business actors is causing harm, states have a duty to protect individuals against that harm. However, for the reasons of specificity and causality, elaborated above, it could be that neither corporations nor specific states view the harm as within their remit. 
Forthcoming in Australian Journal of Human Rights - draft, please do not cite without permission.

This is reasonable from an individualistic perspective (no single actor bears full responsibility) but unreasonable from a collective perspective (states share a universal human rights duty to protect individuals from harm) (Universal Declaration of Human Rights, Art. 28; Gibney 2013b). A collective mechanism of this type would allow states to perform their duty without overburdening particular jurisdictions.

The UNGPs state that corporations bear responsibility for their own contributions only and should remedy them. However, determining a particular corporation's contribution is difficult in the case of large-scale impacts. It would be impossible to disaggregate the contributions of one of the carbon majors, a leading technology company, and a large bank to a climate change-related disaster, for example. To hold firms accountable for their impacts, it makes sense to partially limit the specificity requirement. All contributors to impacts would pay into the fund broadly in line with their own contribution and the fund would then provide compensatory remedy to victims. As explained below, the TFV could be disaggregated by different types of impact, so that there would be, in effect, one fund for victims of climate change paid for by polluters, one for victims of the transnational food regime, etc. This goes beyond the literal wording of the UNGPs but retains the object, purpose and ethos of the principles therein.

There are several possible models for this fund. Three areas with links to human rights impacts provide precedents: climate change, mass automation, and the egregious human rights abuses prosecuted at the International Criminal Court. In each of these areas, remedial (including "adaptive") funds have been established. These models also provide further evidence that some businesses recognise their own contributions to large-scale impacts and are attempting to address them. 
Forthcoming in Australian Journal of Human Rights - draft, please do not cite without permission.

The Warsaw International Mechanism for Loss and Damage Associated with Climate Change Impacts (WIM), established under the 2013 UN Framework Convention for Climate Change, requires developed states to assist developing states to manage climate change impacts by imposing financial obligations on them. However, the 2015 Paris Agreement (Art. 51) confirms 'that [WIM] does not involve or provide a basis for any liability or compensation'. Rather, it is a flexible requirement for an adaptive fund that states can meet in a variety of ways, such as by technology transfers. Article 9(1) of the 2015 Paris Agreement states: 'Developed country Parties shall provide financial resources to assist developing country Parties with respect to both mitigation and adaptation in continuation of their existing obligations under the Convention'. This echoed an agreement in 2009 wherein states committed to mobilising $\$ 100$ billion a year by 2020 from public and private sources to support climate action in developing countries (World Resources Institute 2015). However, there are significant doubts about whether this will be achieved (World Resources Institute 2015). In a survey of the state-based climate reparations landscape, Mayer $(2017,189,216)$ concluded that, at best, state-based climate reparations may be feasible in a diminutive form.

Lyster $(2015,140)$ has proposed that WIM should include a 'Climate Disaster Response Fund', to be funded by the 200 largest listed carbon majors 'by estimated reserves of fossil fuels'. This, Lyster $(2015,146)$ claims, balances causal responsibility and the ability to pay. Under this proposal, '[v]ictims in all developing countries that are particularly vulnerable to climate disasters should be able to claim against the Climate Disaster Response Fund' (Lyster 2015, 147). The Executive Committee of WIM would 
Forthcoming in Australian Journal of Human Rights - draft, please do not cite without permission.

decide the quantity of the levy, based on 'the average uncompensated damages arising from the various extreme weather events and disasters' (Lyster 2015, 148).

Similar funds have been established domestically, broadly in line with the “polluter pays principle” (Tilton 2016). In 1980, the US established the Comprehensive Environmental Response, Compensation and Liability Act (CERCLA). This established a "superfund", 'financed primarily by excise taxes on petroleum and chemical feedstocks, to enable the government to pay for the cleaning up of hazardous chemicals', although the tax expired in 1995 (Lyster 2015, 142). Three international instruments have been drafted to address oil spills, one of which is financed in part by contributions levied on private companies (IPIECA and ITOPF 2007, 6). In Australia, the James Hardie Group eventually agreed to pay into an ongoing compensatory scheme, the James Hardie Fund, for historical and ongoing harm caused by its use of asbestos (Moerman and van der Laan 2015).

As mentioned above, Greenpeace et al. (2015, 61-62) have petitioned the PCHR to hold accountable the largest 50 investor-owned carbon majors for the severe current and future impacts of climate change, including damage caused by extreme weather events. The petition identified that these firms contributed $21.5 \%$ of estimated global industrial emissions to 2010 and sought for each company to be held responsible in line with its emissions (Greenpeace et al. 2015, 6, 37). Greenpeace et al. (2015, 12-13, 29$33,35-38$ ) refer extensively to the UNGPs in their petition, including by referring to the corporate responsibility to respect human rights, human rights impacts, and access to remedy.

Beyond climate justice, mass automation has provoked the most attention. In 2017, Google, when it announced its "Grow with Google" initiative, committed to 
Forthcoming in Australian Journal of Human Rights - draft, please do not cite without permission.

giving \$1 billion over five years to organisations on the front-line of 'closing the world's education gap, helping people prepare for the changing nature of work, and ensuring that no one is excluded from opportunity over five years' (Pichai 2017). Through this initiative, Google is directly (though, perhaps not adequately) addressing its impacts on socio-economic rights, such as to work and to just work.

A robot tax, most famously proposed by Bill Gates, provides a more comprehensive variant of Google's philanthropy. In its basic form, this proposes an additional tax on automated mechanisms that displace human workers. Such a mechanism would serve the twin purpose of slowing the pace of automation by increasing its costs to ensure a more harmonious transition and providing finance for a social safety net (Floridi 2017). There are many variations of this idea. Some are predicated simply on avoiding harm to workers (Freeman 2015); others attempt more transformative shifts (Srnicek and Williams 2015). Abbott and Bogenschneider (2018) argue that the tax system is built to tax labour not capital and currently incentivises automation over workers, even where the costs may otherwise be equal. Although distinct, this idea bears some similarity to a TFV, in that it attempts to provide an ongoing form of remedy (though, this term is not used) for those who are affected by automation. As such, it would address the endemic harm resulting from economic activity in a similar way to a TFV.

The International Criminal Court's TFV, established by the Rome Statute, aims to provide reparations to victims and to rebuild communities affected by international crimes. It is also used to establish assistance programs for victims in communities where the Office of the Prosecutor is actively investigating international crimes and to administer reparation orders made by the Court. Past assistance programmes have taken 
Forthcoming in Australian Journal of Human Rights - draft, please do not cite without permission.

the form of reconstructive surgery services, trauma counselling and vocational training (Trust Fund for Victims, n.d.). The TFV thereby helps to provide remedy for both individuals and communities. As such, it provides, in theory, a reasonably comprehensive form of justice, even if the Office of the Prosecutor is limited to targeting specific, egregious cases (Moffett 2012, 1207-1209).

A further example is the UN Compensation Commission, which was established to compensate victims of Iraq's invasion of Kuwait (Heiskanen and O’Brien 1998).

\section{A Trust Fund for Victims for victims of human rights impacts}

A TFV for victims of human rights impacts would help to remedy impacts that cannot be addressed by more traditional means, such as criminal or tort law, and to address the current problem of unaccountable contributors to human rights impacts. Many of the models surveyed above have useful elements. The CERCLA superfund and the robot tax collect funds for adaption and remedy from firms causing or at risk of causing harm without attributing moral fault to them. The ICC's TFV is useful for its broad approach to victims and remedy. The Greenpeace petition demonstrates the utility of the UNGPs for dealing, conceptually, with large-scale impacts. In this section, this paper provides a preliminary outline of the possible form and limits of a TFV under pillar three.

Access to an effective remedy has 'both procedural and substantive aspects' (UNWG 2017, para. 14).

An important procedural aspect is who could make claims and how they could do so. It would be sensible to allow a broad range of parties, including states, victims and third parties, to make claims and to prioritise claims from states that lack the capacity to provide remedy themselves. NCPs already take this approach to claims (OECDWatch 2017, 35). 
Forthcoming in Australian Journal of Human Rights - draft, please do not cite without permission.

Another important procedural aspect is who could determine claims and on what specific principles their determinations should be based. A neutral body, similar to a non-judicial grievance mechanism, should decide on claims. Its constitution would depend on whether it had been established by companies, states, or an international organisation, such as the UN. The standards outlined in the UNGPs, and elaborated in this paper, would provide guidance as to which claims are permissible, but some questions, such as the scope of and any limitations on legitimate claims, would remain. For example, would any harm capable of being causally linked to business activity fall within the TFV's scope, or only harm arising from a delineated set of acts, such as polluting? Would responsibility be restricted to major contributors, such as the carbon majors in the case of climate change, or would it extend further?

Substantively, the only function of the TFV would be to provide financial compensation to victims. In addition to direct transfers to victims, this compensation could, where it would provide substantive remedy, take the form of funding for largescale projects, such as projects to address land degradation caused by climate change. The ICC's TFV, which prioritises affected communities' needs over theoretical limitations on what constitutes a substantive remedy, would be a good model for this. For example, in Uganda the TFV funds various health, women's and children's services (Trust Fund for Victims, n.d.). Since the proposed TFV for victims of human rights impacts is intended to complement other available forms of remedy, it should not prejudice individuals from making claims elsewhere.

An important substantive aspect is which impacts should be covered and which impacts should be prioritised. This requires the balancing of several elements: the extent of the corporate contribution to the impact; the severity of the impact; the extent to 
Forthcoming in Australian Journal of Human Rights - draft, please do not cite without permission.

which contributors can be targeted through other (e.g. judicial) means; and how difficult or unaffordable it would be for the relevant state(s) to remedy the impact. For example, if a developed state and a developing state were affected similarly by a climate change impact, the latter should be given priority under the TFV. This paper tentatively proposes that the second element - the severity of the impact - should be prioritised over the others, as this would best centre rights holders' needs. As long as responsibility for the harm caused rests primarily with corporate actors, rather than states, and other grievance mechanisms would not work to establish specific liability, funds from the TFV could be used. State wrongdoing would be generally excluded, even where corporate complicity was evident. So would impacts by small groups of firms that could better be addressed through tort law. In essence, the TFV would act as a "back-up" form of remedy, where others would be likely to fail. The TFV could also be used, in extremis, to provide emergency relief where other claims related to the impact are pending.

The full scope, limits and priorities of the fund would require further research and debate. Some large-scale impacts, such as impacts that occur through domestic housing markets, are more amenable to state regulation than others, such as impacts that occur through the global food chain. Ideally, all large-scale impacts, regardless of the form of impact, would be included, in principle, based on the prioritisation of rights holders. However, realistically, spending priorities will have to be determined. With this in mind, it could also be sensible to disaggregate the TFV, either by form of contribution or affected right. In that case, the TFV would, in effect, be composed of separate funds for, for example, climate change impacts, housing, food, etc. Each of these separate funds would be funded by the relevant contributors. This would add 
Forthcoming in Australian Journal of Human Rights - draft, please do not cite without permission.

specificity and assist in aligning the TFV to the UNGPs' objective of having firms remedy their own contributions. The problem with this approach, though, is that it, at least partially, elevates the form of contribution above the needs of rights holders.

There are various possible approaches to determining which corporations should pay into the TFV and how much they should pay. By taking a disaggregated approach, it could target all those involved in climate change on a sliding scale. The carbon majors would make the highest contributions; firms like Apple (whose contributions are smaller than those of the carbon majors but are still significant, as detailed below) would make a mid-level contribution; and smaller firms that are not directly engaged in polluting activities but, nonetheless, inevitably contribute to climate change would make a lower contribution. For housing, large investors like Blackstone would pay more, and those assisting, such as their investors or large suppliers, and smaller contributors to the cumulative impact would pay less.

To get some idea of scale, this section will briefly discuss some theoretical base quantities. It is worth noting at the outset that no large company is likely to avoid such contributions completely. Apple, British American Tobacco and Berkshire Hathaway topped the Fortune 500 list for 2017. British American Tobacco's links to human rights impacts are obvious. Beyond the impact of selling tobacco itself, there are significant impacts at the growing stage, particularly on the environment and workers (Ramos 2018). Apple $(2017 ; 2018,6)$ produced 27.5 million metric tons of greenhouse gases in 2017, and a single Apple iPhone X creates 79kg of carbon emissions in its lifetime. Apple also 'enables and encourages' harmful mining operations, such as for coltan, without adequate mitigation (Amnesty International 2016). Berkshire Hathaway (n.d.) is a holding company that owns numerous companies including airline, fast food, and real- 
Forthcoming in Australian Journal of Human Rights - draft, please do not cite without permission.

estate businesses. Each sector presents clear risks of contributions to human rights impacts, including environmental harm and impacts on health and the right to housing.

On the question of how much a contributor should pay into the TFV, McKinsey\&Company $(2015,29-30)$ states that, in 2015, total global corporate profits were $\$ 7.2$ trillion (or $9.8 \%$ of global GDP). In 1980, the figure was $\$ 2$ trillion (or $7.2 \%$ of global GDP). The largest 500 corporations in the world made $\$ 1.7$ trillion profit in 2017 (Fortune, n.d.). Profits are also expanding at an unusually high rate. S\&P 500 companies made average profits of $17.5 \%$ in 2018 , though this is predicted to decline (Cox 2018). The long-term average since 1950 is 6.6\% (Tully 2017). For the operation of the TFV to remain practical, small firms should be exempt. This would follow the approach taken in, for example, the UK's 2015 Modern Slavery Act, which only requires reporting from companies with an annual turnover above $£ 36$ million (s. 54(2)). As guidance, if all corporations included in the McKinsey\&Company data were targeted with an average $1 \%$ levy on profits (which would be an expansive approach to the TFV), they would pay $\$ 72$ billion into the TFV annually. If all corporations included in the Fortune 500 were so targeted (which would be a more minimalistic approach to the TFV), they would pay $\$ 17$ billion. Those firms within the selection that make greater contributions to human rights impacts would pay more, and some could be excluded, based on their ethical credentials. Even taking account of compliance difficulties and hidden profits, a TFV could be transformative, without imposing overly onerous burdens on corporations. Indeed, corporate tax rates have fallen so much during the era of globalisation that this new levy would hardly make up for the shortfall (Piketty and Saez 2007). As the levy would vary, based on level of contribution to 
Forthcoming in Australian Journal of Human Rights - draft, please do not cite without permission.

impact, it could also help create virtuous feedbacks, reducing the extent of harmful, profit-motivated practices.

\section{Conclusion}

This paper has argued that corporations contribute to ongoing, large-scale adverse human rights impacts as part of their intrinsic economic activity. The nature of largescale impacts, as defined in this paper, means that the remedial mechanisms that pillar three of the UNGPs advocates are ill-suited to holding corporations to account for these impacts. This paper has argued that responsibility under the UNGPs requires there to be remedial mechanisms that are capable of addressing all adverse human rights impacts. It has therefore proposed an additional remedial form, a TFV, in line with the requirements of pillar two of the UNGPs, in order to better hold corporations accountable and provide remedy to victims of human rights impacts. Further research and debate is needed, particularly into the extent of contributory responsibility under the UNGPs and how contributions will be quantitatively assessed. Nonetheless, it is hoped that this paper has provided a technical and moral rationale for such a mechanism under the UNGPs and, as such, can contribute to ongoing debates around the functional enactment of the corporate responsibility to respect human rights. 
Forthcoming in Australian Journal of Human Rights - draft, please do not cite without permission.

\section{References}

\section{Domestic legislation}

$U K$

Modern Slavery Act 2015

$U S$

Comprehensive Environmental Response, Compensation and Liability Act 1980

\section{International legal materials}

International Covenant on Economic, Social and Cultural Rights, 16 December 1966, 993 UNTS 3.

Paris Agreement under the United Nations Framework Convention on Climate Change, 12 December 2015.

Rome Statute of the International Criminal Court, 17 July 1998, 2187 UNTS 3.

United Nations Guiding Principles on Business and Human Rights, 25 May 2011, A/HRC/17/31/Add.3.

Universal Declaration of Human Rights, 10 December 1948, UNGA Res. 217 A(III).

\section{Other references}

Abbott, Ryan and Bret Bogenschneider. 2018. "Should robots pay taxes: tax policy in the age of automation". Harvard Law and Policy Review 12 (1): 145-175.

Amnesty International. 2016. "This Is What We Die For": Human Rights Abuses in the Democratic Republic of the Congo Power the Global Trade in Cobalt. https://www.amnesty.org/download/Documents/AFR6231832016ENGLISH.pdf

Apple. 2017. iPhone X Environmental Report.

https://images.apple.com/environment/pdf/products/iphone/iPhone_X_PER_sept 2017.pdf

Apple. 2018. Environmental Responsibility Report.

https://www.apple.com/environment/pdf/Apple_Environmental_Responsibility_ Report_2018.pdf 
Forthcoming in Australian Journal of Human Rights - draft, please do not cite without permission.

Arnold, Denis. 2016. "Corporations and human rights obligations". Business and Human Rights Journal 1 (2): 255-275.

Augenstein, Daniel. 2018. "Torture as tort? Transnational tort litigation for corporaterelated human rights violations and the human right to a remedy". Human Rights Law Review 18 (3): 593-612.

Berkshire Hathaway. n.d. "Links to subsidiary companies". Accessed 22 October 2019. http://www.berkshirehathaway.com/subs/sublinks.html

Birchall, David. 2019a. "Any act, any harm, to anyone: the transformative potential of 'human rights impacts' under the UN Guiding Principles on Business and Human Rights”. University of Oxford Human Rights Hub Journal 1 (2): 120147.

Birchall, David. 2019b. "The consequentialism of the UN Guiding Principles on Business and Human Rights: towards the fulfilment of 'do no harm'”. Electronic Journal of Business Ethics and Organisation Studies 24 (1): 28-39.

Birchall, David. Forthcoming. "Between apology and utopia: the indeterminacies of the zero draft Treaty on Business and Human Rights". Suffolk Transnational Law Review 40 (2).

Bohoslavsky, Juan Pablo. 2015. Illicit Financial Flows, Human Rights and the Post2015 Development Agenda [Interim Report of the Independent Expert], 10 February. Human Rights Council. A/HRC/28/60.

CDP. 2017. The Carbon Majors Database: Carbon Majors Report 2017. https://b8f65cb373b1b7b15febc70d8ead6ced550b4d987d7c03fcdd1d.ssl.cf3.rackcdn.com/cms/reports/docume nts/000/002/327/original/Carbon-Majors-Report-2017.pdf?1499691240

CESCR (Committee on Economic, Social and Cultural Rights). 1990. General Comment 3: The Nature of States Parties' Obligations. E/1991/23.

CESCR (Committee on Economic, Social and Cultural Rights). 1991. General Comment 4: The Right to Adequate Housing. E/1992/23.

Chadwick, Anna E. 2018. "Gambling on hunger? The right to adequate food and commodity derivatives trading". Human Rights Law Review 18 (2): 233-265.

Courtis, Christian, Nicholas Lusiani and Aoife Nolan. 2014. "Two steps forward, no steps back? Evolving criteria on the prohibition of retrogression in economic and 
Forthcoming in Australian Journal of Human Rights - draft, please do not cite without permission.

social rights". In Economic and Social Rights after the Global Financial Crisis, edited by Aoife Nolan, 121-145. Cambridge: Cambridge University Press.

Cox, Jeff. 2018. "Corporate profits are reaching their peak and history shows that's bad news for the stock market" $C N B C, 5$ November. https://www.cnbc.com/2018/11/05/corporate-profits-are-peaking-and-thatsbeen-bad-news-for-the-stock-market.html

Darcy, Shane. 2016. “"The elephant in the room': corporate tax avoidance and business and human rights". Business and Human Rights Journal 2 (1): 2-30.

De Schutter, Olivier. 2008. Background Note: Analysis of the World Food Crisis by the UN Special Rapporteur on the Right to Food, Olivier De Schutter. https://www2.ohchr.org/english/issues/food/docs/SRRTFnotefoodcrisis.pdf

De Schutter, Olivier. 2009. Crisis into Opportunity: Reinforcing Multilateralism [Report of the Special Rapporteur], 21 July 2009. A/HRC/12/31.

De Schutter, Olivier. 2012. "Commentary to the Maastricht Principles on Extraterritorial Obligations of States in the Area of Economic, Social and Cultural Rights". Human Rights Quarterly 34 (4): 1084-1169.

Deva, Surya. 2013. "Treating human rights lightly: a critique of the consensus rhetoric and the language employed by the Guiding Principles". In Human Rights Obligations of Business: Beyond the Corporate Responsibility to Respect?, edited by Surya Deva and David Bilchitz, 78-104. Cambridge: Cambridge University Press.

Deva, Surya and Farha, Leilani. 2019. Mandates of the Working Group on the issue of human rights and transnational corporations and other business enterprises and the Special Rapporteur on adequate housing as a component of the right to an adequate standard of living, and on the right to non-discrimination in this context. https://www.ohchr.org/Documents/Issues/Housing/Financialization/OL_OTH_1 7_2019.pdf

DIHR (Danish Institute of Human Rights). 2016. Human Rights Impact Assessment: Guidance and Toolbox. https://www.humanrights.dk/sites/humanrights.dk/files/media/dokumenter/busin 
Forthcoming in Australian Journal of Human Rights - draft, please do not cite without permission.

ess/hria_toolbox/hria_guidance_and_toolbox_final_may22016.pdf_223795_1_1 .pdf

DIHR (Danish Institute of Human Rights), MCRB (Myanmar Centre for Responsible Business) and IHRB (Institute for Human Rights and Business). 2015. Myanmar Tourism Sector Wide Impact Assessment.

https://www.humanrights.dk/sites/humanrights.dk/files/media/dokumenter/udgiv elser/hrb_2015/swia_tourism_myanmar_2015.pdf

Farha, Leilani. 2017. Report of the Special Rapporteur on Adequate Housing as a Component of the Right to an Adequate Standard of Living, and on the Right to Non-discrimination in this Context, 18 January. A/HRC/34/51.

Feintrenie, Laurene, Lucy Rist, and Patrice Levang. 2010. "The livelihood impacts of oil palm: smallholders in Indonesia”. Biodiversity and Conservation 19 (4): 1009-1024.

Ferrando, Tomaso. 2019. "Financialisation of the transnational food chain: from threat to leverage point?". Transnational Legal Theory 9 (3-4): 316-342.

Floridi, Luciano. 2017. "Robots, jobs, taxes, and responsibilities". Philosophy and Technology 30 (1): 1-4.

Fortune. n.d. "Fortune Global 500". Accessed 22 October 2019. https://fortune.com/global500/search/

Freeman, Richard. 2015. "Who owns the robots rules the world" IZA World of Labor. Accessed 22 October 2019. https://wol.iza.org/articles/who-owns-the-robotsrules-the-world/long

Gibney, Mark. 2013a. “On terminology: extraterritorial obligations”. In Global Justice, State Duties: The Extraterritorial Scope of Economic, Social and Cultural Rights in International Law, edited by Malcolm Langford, Wouter Vandenhole, Martin Scheinin and Willem van Genugten, 32-50. Cambridge: Cambridge University Press.

Gibney, Mark. 2013b. "Establishing a social order and international order for the realization of human rights". In The State of Economic and Social Rights, edited by Lanse Minkler, 251-270. Cambridge: Cambridge University Press.

Greenpeace (Greenpeace Southeast Asia [Philippines]), Philippine Rural Reconstruction Movement, Sentro Ng Mga Nagkakaisa At Progresibong Manggagawa, Dakila, 
Forthcoming in Australian Journal of Human Rights - draft, please do not cite without permission.

Philippine Alliance of Human Rights Advocates, Philippine Human Rights Information Center, Mother Earth Foundation, et al. 2015. Petition Requesting for Investigation of the Responsibility of the Carbon Majors for Human Rights Violations or Threats of Violations Resulting from the Impacts of Climate Change. https://www.greenpeace.org/archiveseasia/ph/PageFiles/735291/Petitioners-and-Annexes/CC-HR-Petition.pdf Heiskanen, Veijo and Robert O’Brien. 1998. “UN Compensation Commission Panel sets precedents on government claims". American Journal of International Law 92 (2): 339-350.

Human Rights Council. 2018. Legally Binding Instrument to Regulate, in International human Rights Law, the Activities of Transnational Corporations and Other Business Enterprises: Zero Draft.

https://www.ohchr.org/documents/hrbodies/hrcouncil/wgtranscorp/session3/draf tlbi.pdf

Human Rights Council. 2019. Legally Binding Instrument to Regulate, in International human Rights Law, the Activities of Transnational Corporations and Other Business Enterprises: OEIGWG [Open-ended Intergovernmental Working Group] Chairmanship Revised Draft 16.7.2019. https://www.ohchr.org/Documents/HRBodies/HRCouncil/WGTransCorp/OEIG WG_RevisedDraft_LBI.pdf

IPIECA (International Petroleum Industry Environmental Conservation Association) and ITOPF (International Tanker Owners Pollution Federation). 2007. Oil Spill Compensation: A Guide to the International Conventions on Liability and Compensation for Oil Pollution Damage. https://www.itopf.org/fileadmin/data/Documents/Company_Lit/IPEICAITOPFC ompensation.pdf

Judson, Ruth A, Richard Schmalensee, and Thomas M. Stoker. 1998. "World carbon dioxide emissions: 1950-2050”. Review of Economics and Statistics 80 (1): 1527.

Kinley, David. 2017. "Artful dodgers: banks and their human rights responsibilities" SSRN, 1 March. https://papers.ssrn.com/sol3/papers.cfm?abstract_id=2926215 
Forthcoming in Australian Journal of Human Rights - draft, please do not cite without permission.

Knox, John. 2016. Climate Change [Report of the Special Rapporteur], 1 February. Human Rights Council. A/HRC/31/52.

Knox, John. 2018. Global Recognition of the Right to a Safe, Clean, Healthy and Sustainable Environment [Report of the Special Rapporteur], 19 July. General Assembly. A/73/188.

Knuckey, Sarah and Eleanor Jenkin. 2015. "Company-created remedy mechanisms for serious human rights abuses: a promising new frontier for the right to remedy?" International Journal of Human Rights 19 (6): 801-827.

Linklater, Andrew. 2011. The Problem of Harm in World Politics: Theoretical Investigations. Cambridge: Cambridge University Press.

Lyster, Rosemary. 2015. “A fossil fuel-funded climate disaster response fund under the Warsaw International Mechanism for Loss and Damage associated with Climate Change Impacts". Transnational Environmental Law 4 (1): 125-151.

Mayer, Benoit. 2017. "Climate change reparations and the law and practice of state responsibility". Asian Journal of International Law 7 (1): 185-216.

McKinsey\&Company. 2015. Playing to Win: The New Global Competition for Corporate Profits. https://www.mckinsey.com/ /media/mckinsey/business\%20functions/strategy\% 20and $\% 20$ corporate $\% 20$ finance/our\%20insights/the $\% 20$ new $\% 20$ global $\% 20 \mathrm{com}$ petition\%20for\%20corporate\%20profits/mgi\%20global\%20competition_full\%2 Oreport_sep\%202015.ashx

McMichael, Philip. 2012. "The land grab and corporate food regime restructuring". Journal of Peasant Studies 39 (3-4): 681-701.

Miller-Dawkins, May, Kate Macdonald and Shelley Marshall. 2016. "Beyond effectiveness criteria: the possibilities and limits of transnational non-judicial redress mechanisms" SSRN, 7 November. https://papers.ssrn.com/sol3/papers.cfm?abstract_id=2865356

Moerman, Lee and Sandra van der Laan. 2015. "Exploring shadow accountability: the case of James Hardie and asbestos". Social and Environmental Accountability Journal 35 (1): 32-48. 
Forthcoming in Australian Journal of Human Rights - draft, please do not cite without permission.

Moffett, Luke. 2017. "Reparations for Victims at the International Criminal Court: A New Way Forward?”. International Journal of Human Rights 21 (9): 12041222.

Musalo, Karen. 2006. "Protecting victims of gendered persecution: fear of floodgates or call to (principled) action". Virginia Journal of Social Policy and the Law 14: $119-157$.

OECD (Organisation for Economic Co-operation and Development). 2011. OECD Guidelines for Multinational Enterprises: 2011 Edition. http://www.oecd.org/daf/inv/mne/48004323.pdf

OECD (Organisation for Economic Co-operation and Development). 2016. Implementing the OECD Guidelines for Multinational Enterprises: The National Contact Points from 2000 to 2015. https://mneguidelines.oecd.org/OECDreport-15-years-National-Contact-Points.pdf

OECDWatch. 2015. Remedy Remains Rare. https://www.oecdwatch.org/wpcontent/uploads/sites/8/2015/06/Remedy-Remains-Rare.pdf

OECDWatch. 2017. Calling for Corporate Accountability. https://www.oecdwatch.org/wp-content/uploads/sites/8/2017/10/Calling-forCorporate-Accountability.pdf

OECDWatch. 2018. The State of Remedy under the OECD Guidelines. https://www.oecdwatch.org/wp-content/uploads/sites/8/2018/06/The-State-ofRemedy-under-the-OECD-Guidelines.pdf

OECDWatch. n.d. "Action Aid Denmark vs. Arla Foods". Accessed 22 October 2018. https://complaints.oecdwatch.org/cases/Case_358

OHCHR (Office of the High Commissioner on Human Rights). 2011. Guiding Principles on Business and Human Rights: Implementing the United Nations 'Protect, Respect and Remedy' Framework. https://www.ohchr.org/documents/publications/GuidingprinciplesBusinesshr_eN .pdf

OHCHR (Office of the High Commissioner on Human Rights). 2016. Key Messages on Human Rights and Climate Change. https://www.ohchr.org/Documents/Issues/ClimateChange/KeyMessages_on_HR _CC.pdf 
Forthcoming in Australian Journal of Human Rights - draft, please do not cite without permission.

Pichai, Sundar. 2017. "Grow with Google: opportunity for everyone” Google, 12 October. https://blog.google/outreach-initiatives/grow-with-google/opportunityfor-everyone/

Piketty, Thomas and Emmanuel Saez. 2007. "How progressive is the US federal tax system? A historical and international perspective". Journal of Economic Perspectives 21 (1): 3-24.

Ramos, Athena. 2018. "Child labor in global tobacco production: a human rights approach to an enduring dilemma". Health and Human Rights 20 (2): 235-248.

Ruggie, John. 2017. Comments on Thun Group of Banks Discussion Paper on the Implications of UN Guiding Principles 13 and 17 in a Corporate and Investment Banking Context.

https://www.ihrb.org/uploads/submissions/John_Ruggie_Comments_Thun_Ban ks_Feb_2017.pdf

Ruggie, John. 2018. "Multinationals as global institution: power, authority and relative autonomy”. Regulation and Governance 12 (3): 317-333.

Scheltema, Martijn. 2013. "Assessing the Effectiveness of Remedy Outcomes of NonJudicial Grievance Mechanisms". The Dovenschmidt Quarterly: 190-197.

Seck, Sara. 2016. "Revisiting transnational corporations and extractive industries: climate justice, feminism, and state sovereignty". Transnational Law and Contemporary Problems 26: 383-413.

Seck, Sara. 2019. "Moving beyond the e-word in the Anthropocene". In The Extraterritoriality of Law: History, Theory, Politics, edited by Daniel S Margolies, Umut Özsu, Maïa Pal and Ntina Tzouvala, 49-66. London: Routledge.

Sepúlveda Carmona, Magdalena. Report of the Special Rapporteur on Extreme Poverty and Human Rights, Magdalena Sepúlveda Carmona, 22 May. Human Rights Council. A/HRC/26/28.

Srnicek, Nick and Alex Williams. 2015. Inventing the Future: Postcapitalism and a World Without Work. London: Verso Books.

Thun Group of Banks. 2017. Paper on the Implications of the UN Guiding Principles $13 \mathrm{~b}$ and 17 in a Corporate and Investment Banking Context. https://www.business- 
Forthcoming in Australian Journal of Human Rights - draft, please do not cite without permission.

humanrights.org/sites/default/files/documents/2017_12_Thun\%20Group\%20of \%20Banks_Paper_UNGPs\%2013b\%20and\%2017.pdf

Tilton, John. 2016. "Global climate policy and the polluter pays principle: a different perspective". Resources Policy 50: 117-118.

Trust Fund for Victims. n.d. "Assistance Programs" Trust Fund for Victims. Accessed 24 February 2019. https://www.trustfundforvictims.org/en/what-wedo/assistance-programmes

Tully, Shaun. 2017. “Corporate profits are soaring. Here's why it can't last” Fortune, 7 December. http://fortune.com/2017/12/07/corporate-earnings-profit-boom-end/

UNWG (United Nations Working Group on Business and Human Rights). 2017. Report of the Working Group on the Issue of Human Rights and Transnational Corporations and Other Business Enterprises, 18 July. A/72/162.

Wettstein, Florian. 2009. Multinational Corporations and Global Justice: Human Rights Obligations of a Quasi-governmental Institution. Stanford: Stanford University Press.

World Resources Institute. 2015. Getting to \$100 Billion: Climate Finance Scenarios and Projections to 2020. https://www.wri.org/publication/getting-100-billionclimate-finance-scenarios-and-projections-2020 